\title{
The Developing of Rhetoric and Grammar by Using Grammarly Chrome at SMAN 3 Lembar Academic Year 2020/2021
}

\author{
Jupri \\ Sekolah Menengah Atas Negeri (SMAN) 3 Lembar \\ Jupri0403@gmail.com \\ Received: $14^{\text {th }}$ June 2021, Revised: $25^{\text {th }}$ May 2021, Accepted: $30^{\text {th }}$ June 2021 \\ Email Correspondence: Jupri0403@gmail.com
}

\begin{abstract}
The purpose of this study is to know whether the using Grammarly Chrome is able to increase students' rhetoric and grammar competence in constructing the report text writing. The method of study used is the class action research (CAR) which consists of two cycles and each of them has four steps such as planning, action, evaluation and reflection. This study focuses on students' competence in constructing an English report text. The data collected method is the students' work sheet result after getting the treatment of teaching learning process with Grammarly Chrom help. The result of study indicated that there was significant increasing of student's competence in terms of constructing the report text. In the $2^{\text {nd }}$ cycle is found the students' work sheet result average is 85 , and there were about $95 \%$ students has achieved score $\geq 75$. While in the $1^{\text {st }}$ cycle is found the students' average is 77 , and there was $63 \%$ students have achieved score $\geq 75$. And students respond in using Grammarly Chrome is found significant interested which's about early 18 students actively followed the process of teaching learning in the $1^{\text {st }}$ cycle, while in the $2^{\text {nd }}$ cycle students who interested increased into 22 students, based on the data, the using Grammarly Chrome may increas students' rhetoric and grammar competence, it could give positive influence in terms of constructing an English writing of the report text.
\end{abstract}

Keywords: rhetoric, grammatical, Grammarly Chrome

\section{INTRODUCTION}

The low students' competence in terms of constructing an English writing report text is indicated by the low result of students' sheet of the second grade of science class of SMAN 3 Lembar in academic year 2020/2021. The low value of students' sheet on writing is caused by the low competence of students' rhetoric and grammar, and most of them get trouble in constructing the generic structure such as general classification, description and function.

Since, rhetoric competence is embedded to students' competence in constructing an English idea, meaning, and communication skill, In this particular study researcher focused on developing students 'rhetoric competence and grammar by using Grammarly Chrome. Jillian Whetstone (1996) explained:

Online at https://journal.universitasbumigora.ac.id/index.php/humanitatis/

DOI $\quad:$ https://doi.org/10.30812/humanitatis.v7i2.1270 
written feedback instructional strategy develop for improving accuracy based on practice research and theory formative feedback has moderate to strong positive effect in many disciplines, and negative feedback that draws attention to linguistic for many play a meaningful role in L2 language development. Because of feedback has a positive strong to improve in variety of discipline in L2 language development, researcher assumed that Grammarly chrome is an appropriate way to develop students' rhetoric and grammar in terms of learning an English writing text. In teaching and learning process feedback is needed by whoever follows the class learning.

Emily Daw explained Students who understand rhetoric have an easier time explaining their ideas through writing. Rhetoric and composition are branches of study that deal with the effective use of words and persuasion. The two words are occasionally used interchangeably, but there are some differences in the emphases of the two disciplines. Composition deals almost exclusively with the written word, while rhetoric refers to persuasion in other contexts as well. Both rhetoric and composition are also considered rhetorical devices, which deal with persuasion in speech or writing. Rhetoric is persuasive communication. That is, it is any form of speech or writing that is intended to convince an audience of a particular point of view rather than to simply convey information. The principles of rhetoric were codified by Aristotle's and other Greek philosophers in ancient times. These principles are still followed by modern speakers in the fields of speech and debate. In a broader sense, rhetoric can refer to the effective use of language in any form of discourse (Zalta, 2010).

Thus, the terms of "rhetoric" dates back to ancient Greece, where it referred to the study or art of oration, or persuasive public speaking. Aristotle, who is considered the father of rhetoric, divided the study into what are known as the five canons of rhetoric: invention, arrangement, style, memorization and delivery. Students of rhetoric in Greece would be taught the most effective ways of persuading their audiences by these means (Zalta, 2010).

The problem of students' competence in constructing an English writing of the report text is experienced not only by students of SMAN 3 Lembar but also most of students of senior high school at the same level as well. And one of solution that researcher offers to overcome the problem is 'Grammarly Chrome Application' to support students conduct the duty of an English writing text. This application will control every word, phrase or paragraph in terms of English document and it will control the mistake or error with the red underline sign automatically. This application is not only shows the error but the properly suggestion as well, so the sentence will be complete meaning.

Aristotle's Rhetoric has had an enormous influence on the development of the art of rhetoric. Not only authors writing in the peripatetic tradition, but also the famous Roman teachers of rhetoric, such as Cicero 
and Quintilian, frequently used elements stemming from the Aristotelian doctrine. Nevertheless, these authors were interested neither in an authentic interpretation of the Aristotelian works nor in the philosophical sources and backgrounds of the vocabulary that Aristotle had introduced to rhetorical theory. Thus, for two millennia the interpretation of Aristotelian rhetoric has become a matter of the history of rhetoric (Zalta, 2010).

Since, experts define rhetoric is concerning with someone 'competence in using an appropriate word to convey the factual object, in this study researcher intents to explore the effectiveness of using Grammarly Chrome to increase students' rhetoric competence. In my view when students are able to choose an appropriate word in context of communication in terms of speaking and written in order to make audiences understand the meaning, it means that they have configured the good rhetoric competence. Meanwhile, when they are not able to convey their thinking, ideas, argument and desire in terms of speaking and written, it means they have low rhetoric competence. In addition, Tasmara (1997) classified There are five purposes of rhetoric such as:

1) To Inform

2) To Convise

3) To Inspire,

4) To Entertain

5) To Actuate (to put into action).

In doing the task every student is being available with one laptop/one student, that is connect to internet, students study online make sure the application has been installed. It link to the face book, email, instagram so that students are able to send the task into the researcher's email.

With the help of Grammarly Chrome students are supposed would able to increase students' competence to construct the report text writing. Beside that students would enjoy learning.

\section{RESEARCH METHOD}

Method of the study in this research is qualitative-descriptive and it is plan in two months. This study will focus on the students' rhetoric and grammar competence in constructing an English writing of report text at second grade science class of SMAN 3 Lembar, West Nusa Tenggara Province. This study is observing the students' competence in constructing the report text with the helping of "Grammarly Chrome program" the objectives of study are describing and exploring learners' rhetoric and grammar competence to support the writing competence in terms of report text. 
The task are given by the teacher in constructing an English writing of the report text in a variety of situation are used as instrument test for measuring learners' rhetoric and grammar competence. This study uses two cycles consisting of four research steps, namely: Planning, Action, and Reflection.

This type of research is classroom action research (CAR). This classroom action research was conducted based on the author's experience during the teaching and learning process in the real class of the second grade of science class SMAN 3 Lembar, it is believed by the researcher that report text learning method using the Grammarly chrome application can improve students' rhetorical and grammatical ability. To obtain the data needed, students are asked to construct various report texts after getting the information in terms of how to use grammarly chrome application, after doing the task, then students' worksheet being submitted and analysed students are asking to check and recheck their work in order to find out errors, then students as soon as possible correct it. This approach will have components similar to other types of research- that is, posing question, collecting data, and then analysing and interpreting those data. However, it is differentiated by the fact that it will be carried out by practitioners investigating their own professional context (David Nunan, 2008). In constructing the text students constant follow the generic structure of report text, namely:

\section{a) General classification}

This field provides general statements about objects that will be discussed further in the text. Thus the reader will be easier to understand the details of the object.

b) Description This section tells about a detailed description of the object being discussed. It specification of the previous section of general classification. Besides that, the objects, phenomena or things mentioned in the first section will be explained in this section

In this study, students were assigned to compose the product-based of the report texts with the help of 'grammarly chrome' application to improve rhetorical and grammatical competence. The results of student work sheet will be analyzed based on rhetorical skills and the appropriate grammar. This study, the researcher focused on students' rhetoric skill and grammar' competence.

The results of students' work sheet in the first cycle were be analyzed carefully as a feedback for the next cycle, in this case the researcher makes a note as an important things due to the accomplishment.

In the second cycle students were asked to rearrange the text in the form of a report text after getting feedback from the teacher and considering the results of group discussions during the learning process of first cycles, students' sheet, and the result of second cycles in constructing an English writing of report texts be considering.

\section{Data analysis method}


The method of data analysis is descriptive-qualitative. The data obtained would be analyzed descriptively, researcher was observing the development value of each cycle after the learning process was treated discussions and teaching learning process was using Grammarly Chrome' helping in terms of constructing report text. The results of students' worksheet in constructing English report text be analysed quantitatively. In the first cycle the data be analysed whether there was any significant effect on the students' competence of rhetoric and grammar after using the help of Grammarly Chrome' application in constructing the text. Then the data obtained in the first cycle were evaluated, and the data obtained in the second cycle were evaluated in order to give conclusion.

\section{FINDING AND DISCUSSION}

The Data about students who carry out the learning process using the help of Grammarly Chrome to improve rhetorical and grammatical skills in writing report texts. In the first cycle, the results of observations on students who used Grammarly Chrome in writing report texts were $63 \%$ of students have achieved the of minimum standard of competent.

Table 1. Data the result of students' competence in constructing the report text.

\begin{tabular}{|c|c|c|c|c|}
\hline \multirow{2}{*}{ Number of students } & \multicolumn{4}{|c|}{ CRITERIA } \\
\cline { 2 - 5 } & Very good & good & enough & less \\
\hline 22 & 4 & 10 & 5 & 3 \\
\hline
\end{tabular}

From the table above, it can be described that students' competence concerning with rhetoric and grammar used in terms of constructing an English writing skill of the report text. The first, It found that there were 4 students got very good scores in using grammar and rhetoric after getting the treatment in process of teaching learning using Grammarly Chrome helped, and the percentage of students competence who get very good score is about $18,18 \%$, the second, it found that 10 students get good score with the percentage of students sample population who gets the good score is about $45,45 \%$, the third there were 5 students got enough, with a percentage of sample population about $22,72 \%$, and the last there were 3 students got less score, with a percentage of $13,63 \%$.

Thus, teaching learning with a good preparation and followed by standards of a high-quality of learning process, discussion and appropriate explanation of the technique of using Grammarly Chrome were able to improve students' rhetoric and grammar in terms of an English writing skill in writing report text. In consequence, the first cycle of the research configure that Grammarly Chrome tool could improve students' rhetorical and grammatical competence in writing of the report texts. The data indicated that the 
percentage of data sample population was about $63 \%$ students have achieved the minimum standard criteria (KKM).

In the second cycle researcher conducted the treatment by asking students to do the task, students were asking to re-arrange an English report text in constructing the report text. The data obtained regarding to the competence of students in constructing the report text.

The data obtained in the second cycle as follow:

Table 2. The result of students' work sheet

\begin{tabular}{|c|c|c|c|c|}
\hline \multirow{2}{*}{$\begin{array}{c}\text { Number of } \\
\text { students }\end{array}$} & Very good & Good & Enough & less \\
\cline { 2 - 5 } & 5 & 16 & 1 & 0 \\
\hline 22 & 5 & & 1 & \\
\hline
\end{tabular}

In the second cycle, firstly, the data obtained that there were 5 students got a very good score in using rhetoric skill and grammar in terms of constructing an English writing of the report text, the percentage of minimum standard showed there were about $22,72 \%$ students of the sample population. The $2^{\text {nd }}$ there were 16 students got a good score, with the percentage of minimum standard assessment (MSA) was about 72,27\%, and there was 1 student got enough score, with the percentage of minimum standard assessment (MSA) was about 4.5\%, and the last there was no any student got less score.

Thus, in the second cycle of the study, it configured the percentage of students who have achieved the higher competence in terms of rhetoric and grammar were about $95 \%$, therefore, in this short study the researcher recommend to all English teachers to apply Grammarly Chrome supporting students' rhetoric competence and grammar in constructing an English writing text significantly develop.

\section{CONCLUSION}

Based on the study conducted at the second grade of science class SMAN 3 Lembar, west Lombok, Nusa Tenggara Province that learning an English writing of the report text in terms develop students rhetoric and grammar with the applying the Grammarly Chrome" significantly increase students rhetoric and grammar. Based on the data obtained in $1^{\text {st }}$ cycle it found that 14 students have achieved the minimum standard with the percentage of sample population about $63 \%$ students. It occur because of some students are not maximum understand the generic of structure, not focused on learning, and some step didn't do maximum by the researcher. And in the $2^{\text {nd }}$ cycles of the study, researcher do the same steps treatment such as planning, action, observe, reflecting. And the reality reflected that there were very 
significant development there were 21 students have achieve the minimum standard of competence, and the percentage of sample population was achieving 95\% students got minimum standard of assessments. So, occasionally researcher recommended all English teachers to give more attention to the rhetoric skill and grammar in terms of writing text and using the Grammarly Chrome as tool to develop students' rhetoric and grammar.

\section{REFERENCES}

David Nunan, K. M. B. (2008). Exploring Second Language Classroom Research: A comprehensive guide. Hinle Boston USA.

Jillian Whetstone. (1996). Everyone's An Author. Tucson Steven Alvarez.

Tasmara, T. (1997). Komunikasi Dakwah. Media Pratama.

Zalta, E. N. (2010). The Stanford Encyclopedia of Philosophy. CSLI publication. 
Online at https://journal.universitasbumigora.ac.id/index.php/humanitatis/ 